OPEN ACCESS

International Journal of Advanced Economics

P-ISSN: 2707-2134, E-ISSN: 2707-2142

Volume 4, Issue 1, P.No. 1-18, January, 2022

DOI: $10.51594 /$ ijae.v4i1.291

Fair East Publishers

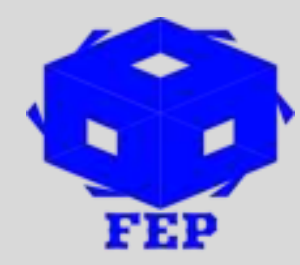

Journal Homepage: www.fepbl.com/index.php/ijae

\title{
SOCIOECONOMIC ANALYSIS OF CASSAVA VALUE CHAIN IN EKITI STATE, NIGERIA
}

\author{
Ibrahim, Ajolola Taibat ${ }^{1}$ \\ ${ }^{1}$ Department of Agricultural Economics and Extension Services, Ekiti State University, \\ Ado-Ekiti, Ekiti State, Nigeria
}

*Corresponding Author: Ibrahim, Ajolola Taibat

Corresponding Author Email: eaakinbola21@ gmail.com

Article Received: $15-12-20$

Accepted: $29-12-21$

Published: 15-01-22

Licensing Details: The author retains the right to this article. The article is distributed under the terms of the Creative Commons Attribution-Non Commercial 4.0 License (http://www.creativecommons.org/licences/by-nc/4.0/) which permits non-commercial use, reproduction, and distribution of the work without further permission provided the original work is attributed as specified on the Journal open access page.

\begin{abstract}
The study investigated the socioeconomic analysis of cassava value chain in Ekiti state, Nigeria using Primary data. The data were sourced with the aid of a well-structured questionnaire and Focused Group Discussion (FGD) interviews. A multistage sampling technique was used to randomly select a total of 300 respondents in the study area. The data were analyzed using descriptive statistics also known as functional analysis. Functional analysis indicates presence of 5 major actors (Input supplier, producers, processors, marketers and consumers) in the value chain. The results showed that two-third of the actors were male with mean age of respondents being 50 years. About $80 \%$ of them were married with average of about 5 persons per household, and over $80 \%$ of them had at least primary school education. On the basis of income level, marketers earn highest income $(\mathrm{N} 314,786)$ among the actors followed by the processors (N224, 500), input suppliers (N196, 666), producers (N151, 041) and consumers (N47, 000). These characteristics have some influence on the demand and supply of cassava products and actors in the cassava value chain. It is therefore recommended that government and non-governmental organization should enact policies and programmes aimed at equipping the actors of cassava value chain with needed skills and expertise as this will expose them the current trends and technologies for effective production. Keywords: Cassava, Value Chain, Focused Group Discussion (FGD), Ekiti State, Nigeria.
\end{abstract}




\section{INTRODUCTION}

Nigeria is the leading producer of cassava tuber in the world with about 45 million mt, average annual production in the country was about 35 million metric tonnes (2002-2008) and the total area under cassava cultivation in Nigeria is about 3.60 million hectares (Adewole and Omeye, 2018). Among the ranking in world production of Cassava, Nigeria is nominal in cassava trade in the international markets as a result of weak segmentation in the cassava value chain and also activities of value chain actors have not been recognized thus farmers concentrate on the value addition using moribund method of cassava production in that they do not recognize that there are other linkages in the value chain which act as a booster to regain losses they encountered during the time of planting and value addition (Henri-Ukoha $e t$ al., 2015; Cucagna and Goldsmith, 2017).

FAO (2006) also defined value chain as the range of activities which are required to bring a product or service from conception, through different phases of production (involving a combination of physical. transformation and the input of various producer services), delivery to final customers, and final disposal after use. United States Agency for International Development-USAID (2006) defined value chain as the full range of activities that are required to bring a product of service from its conception to its end use including all the market channels available to all firms. The value chain concept vividly explains the activities of the chain actor who actually transact a particular product as it moves through the value chain include input (e.g. seed suppliers, farmers, traders, processors, transporters, wholesalers, retailers and final consumers (Mandal et al., 2003; Adewole,2018; Oguwande et al., 2020). The broad objective of the study was therefore to examine the analysis of cassava value chain in Ekiti State, Nigeria. To actualize this, the study described the socio-economic characteristics of actors in the cassava value chain; described the entire chain, showing dependencies and linkages and finally examined the actors of the cassava value chain in the study area.

The relevance of this study is more in this present time when crucial information is needed on the discussion of agricultural reforms through value addition, and the various linkages in the cassava value chain, the strength and signal transmission between different levels of the market that will translate to a profitable enterprise. It will be an eye opener into various products of cassava value chain that are more profitable in terms of income generations and job opportunities in the study area.

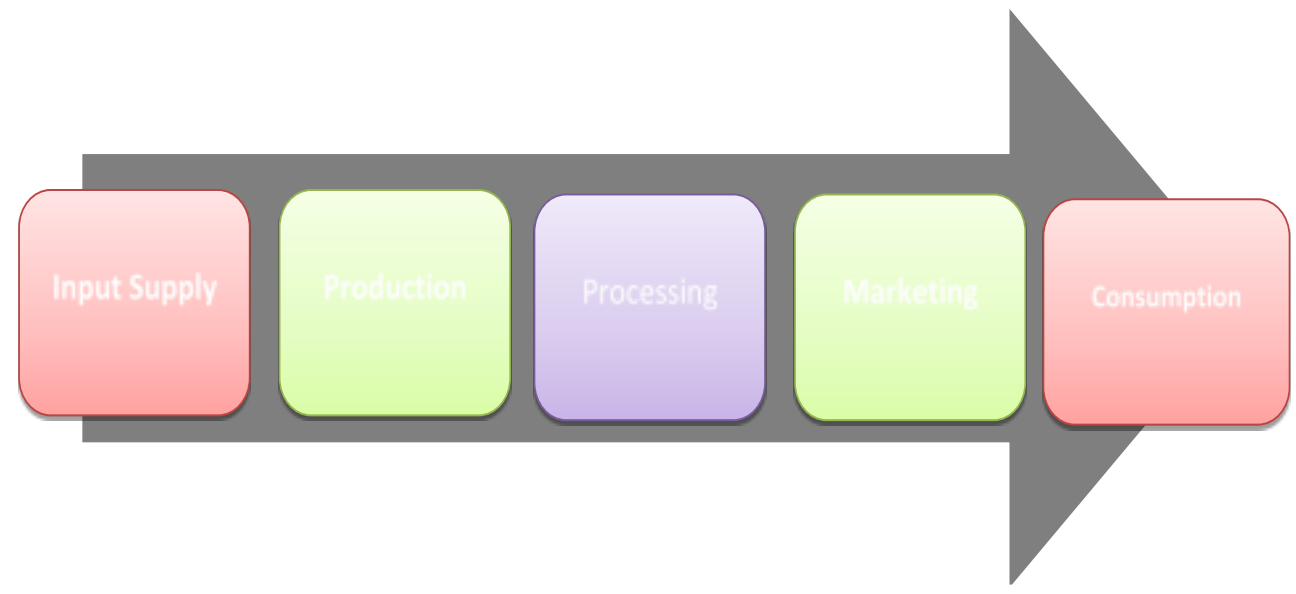

Figure 1: Five stages of a value chain Source: UNIDO, (2009) 


\section{Study Area}

\section{MATERIALS AND METHODS}

The research was carried out in Ekiti State. The State was carved out from old Ondo State on October 1, 1996.It lies between $7^{0} 15^{1}$ and $8^{0} 7^{1}$ North of the equator and longitude $4^{0} 47^{1}$ and $5^{0} 45^{1}$ East of the Greenwich Meridian (Figure 2). The State is bounded to the North by Kwara and Kogi States, to the South and East by Ondo State and to the West by Osun State (Encarta, 2009). The map of Ekiti State is as shown in Figure 4.Ekiti State has a mean annual rainfall of about $1400 \mathrm{~mm}$ and a mean annual temperature of $27^{\circ} \mathrm{C}$. Its vegetation ranges from Rain forest in the South to Guinea savannah in the North with soil largely rich in organic minerals thereby making the State a major producer of both tree and food crops.

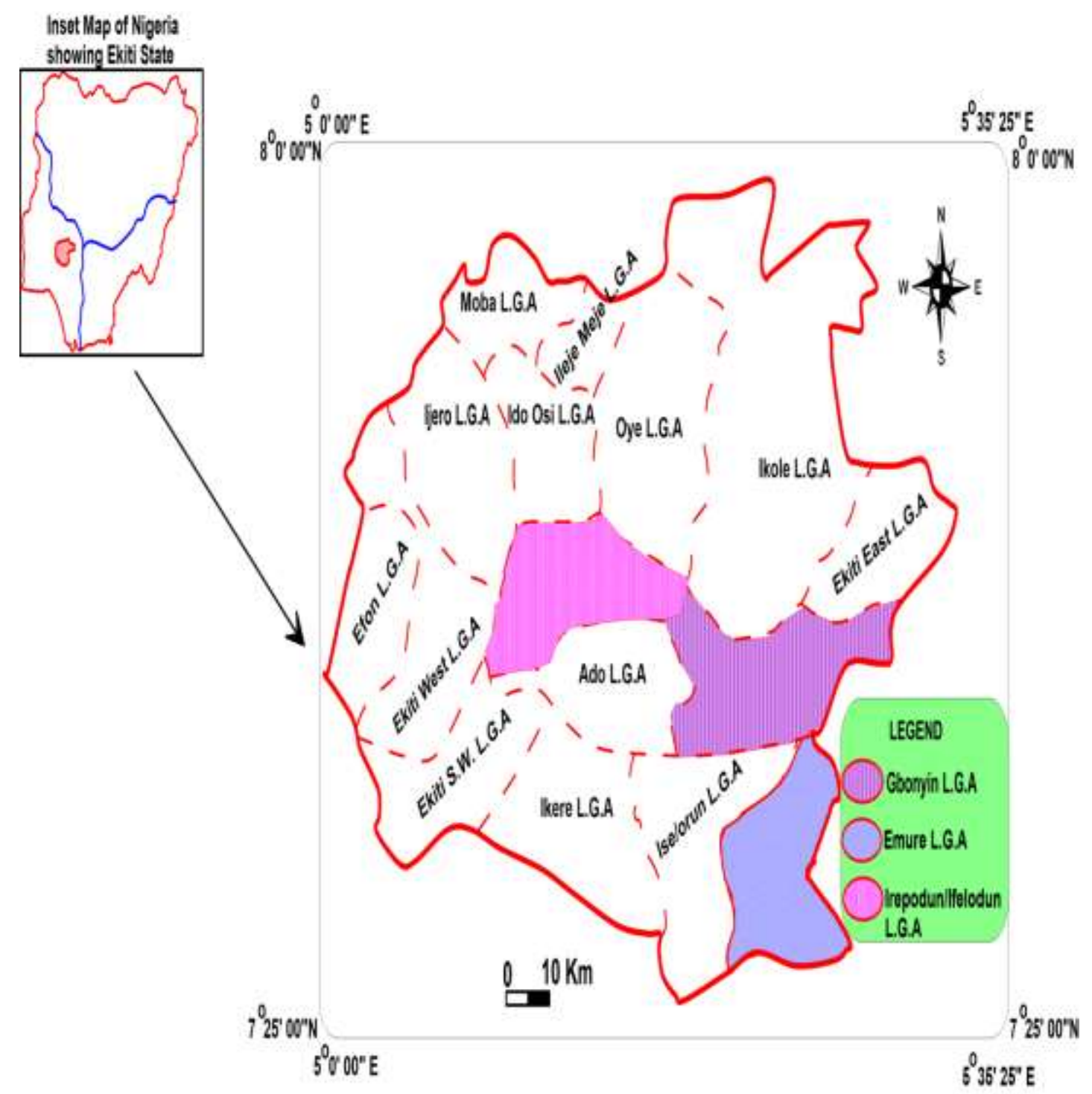

Figure 2: Map of the Study Area

\section{Sampling Procedure and Sample Size}

The respondents for this study were all actors (input providers, farmers, processors, marketers and consumers) in the cassava value chain in the study area. The respondents were chosen using a multi-stage sampling technique. In the first stage; six communities were purposively selected due to the prevalence of cassava cultivation and processing. Snowball sampling technique was used to select twelve (12) farmers, twelve (12) processors while random 
sampling was used to select twelve (12) consumers for each of these communities. Again, purposive sampling technique was used to select three (3) major markets known for the sales of cassava and cassava products in the study area. Using simple random sampling procedure, twenty-five (25) marketers and five (5) input suppliers were selected from each of these markets. Total numbers of actors in the cassava value chain were three hundred and six (306).

\section{Methods of Data Analysis}

Socioeconomic factors of the respondents such as age, sex, religion, years of formal education, years of experience, and other factors in the cassava value chain in the study area were analyzed using descriptive statistics such as frequency counts and percentages (functional analysis). The entire chain, showing dependencies and linkages were described using descriptive statistics (functional analysis). This section involved all actors of the chain; they include input suppliers, farmers, processors, marketers and consumers.

\section{RESULTS AND DISCUSSION}

\section{Socio-Economic Characteristics}

The socio-economic characteristics described for this study are sex, age, religion, marital status, highest educational level and membership of social organization.

\section{Sex}

The Sex distribution of the actors in cassava value chain was presented in Table 3.1.1 .It revealed that $86.7 \%$ of the input suppliers were males, $69.4 \%$ of the producers were males, and $66.7 \%$ of the processors were females. Also, about average $58.7 \%$ of marketers were females and majority $77.9 \%$ of the consumers were female. This implies that both sexes were well represented in the cassava value chain and the dominance of male in the production could be as a result of cultural land tenure system which gives preference to males inheriting land accounts for more male involvement in the segment. Females are left to do the other activities which did not require land ownership and which were less tasking. This assertion is supported by the finding of Kaminki (2013) and Ayodele (2016).

Table1

Distribution of Respondents by Sex

\begin{tabular}{|c|c|c|c|c|c|c|c|c|c|c|}
\hline Sex & Input sup & iers & Producers & & Processor & & Marketers & & Consumer & \\
\hline Male & $\begin{array}{l}\text { Frequenc } \\
\mathrm{y} \\
13\end{array}$ & $\begin{array}{l}\text { Perce } \\
\mathrm{nt} \\
86.7\end{array}$ & $\begin{array}{l}\text { Frequenc } \\
\mathrm{y} \\
33.3\end{array}$ & $\begin{array}{l}\text { Perce } \\
\text { nt } \\
50\end{array}$ & $\begin{array}{l}\text { Frequenc } \\
\mathrm{y} \\
24\end{array}$ & $\begin{array}{l}\text { Perce } \\
\text { nt } \\
31\end{array}$ & $\begin{array}{l}\text { Frequenc } \\
\mathrm{y} \\
41.3\end{array}$ & $\begin{array}{l}\text { Perce } \\
\text { nt } \\
69.4\end{array}$ & $\begin{array}{l}\text { Frequenc } \\
\mathrm{y} \\
16\end{array}$ & $\begin{array}{l}\text { Perce } \\
\text { nt } \\
23.5\end{array}$ \\
\hline $\begin{array}{l}\text { Femal } \\
\mathrm{e}\end{array}$ & 2 & 13.3 & 66.7 & 22 & 48 & 44 & 58.7 & 30.6 & 56 & 77.9 \\
\hline Total & 15 & 100 & 100 & 72 & 72 & 75 & 100 & 100 & 72 & 100 \\
\hline
\end{tabular}

Source: Computed from Field Survey, 2018

\section{Age of the Respondents}

The mean ages of the actors in the cassava value chain revealed that most of them reached the age of 50 years. This signified that able-bodied people were involved in the cassava value chain; this can be the result of frequent information received on the value addition in cassava which can lead to improvement in their wellbeing and the economy of the state. Again, the results are in agreement with Olayemi (2004) who opined that for farmers to be productive in farm chores, they must be young and active in order to contribute meaningful labour input into all the stages of production for efficient output realization which in turn results in consumptive and income opportunities with proportional household welfare. 
Table 2

Age Distribution of Respondents

\begin{tabular}{|c|c|c|c|c|c|c|c|c|c|c|}
\hline \multirow[t]{2}{*}{ Age } & \multicolumn{2}{|c|}{ Input suppliers } & \multicolumn{2}{|l|}{ Producers } & \multicolumn{2}{|c|}{ Processors } & \multicolumn{2}{|c|}{ Marketers } & \multicolumn{2}{|c|}{ Consumers } \\
\hline & $\begin{array}{l}\text { Frequen } \\
\text { cy }\end{array}$ & $\begin{array}{l}\text { Perce } \\
\mathrm{nt}\end{array}$ & $\begin{array}{l}\text { Frequen } \\
\text { cy }\end{array}$ & $\begin{array}{l}\text { Perce } \\
\mathrm{nt}\end{array}$ & $\begin{array}{l}\text { Frequen } \\
\text { cy }\end{array}$ & $\begin{array}{l}\text { Perce } \\
\mathrm{nt}\end{array}$ & $\begin{array}{l}\text { Frequen } \\
\text { cy }\end{array}$ & $\begin{array}{l}\text { Perce } \\
\text { nt }\end{array}$ & $\begin{array}{l}\text { Frequen } \\
\text { cy }\end{array}$ & $\begin{array}{l}\text { Perce } \\
\mathrm{nt}\end{array}$ \\
\hline$<31$ & & & 14 & 19.4 & 2 & 2.8 & & & 18 & 26.7 \\
\hline 31 to 40 & 5 & 33.3 & 22 & 30.6 & 9 & 12.5 & 15 & 20.0 & 10 & 13.3 \\
\hline 41 to 50 & 4 & 26.7 & 15 & 20.8 & 26 & 36.1 & 40 & 53.3 & 34 & 46.7 \\
\hline 51 to 60 & 5 & 33.3 & 21 & 29.2 & 35 & 48.6 & 17 & 22.7 & 10 & 13.3 \\
\hline$>60$ & 1 & 6.7 & & & & & 3 & 4.0 & & \\
\hline Total & 15 & 100.0 & 72 & 100.0 & 72 & 100 & 75 & 100 & 72 & 100 \\
\hline $\begin{array}{l}\text { Minimu } \\
\mathrm{m}\end{array}$ & 33.0 & & 27 & & 23.0 & & 68.0 & & 28.0 & \\
\hline $\begin{array}{l}\text { Maximu } \\
\text { m }\end{array}$ & 65.0 & & 57 & & 60.0 & & 32.0 & & 60.0 & \\
\hline Mean & 47.2 & & 42.3 & & 48.0 & & 48.0 & & 42.0 & \\
\hline $\begin{array}{l}\text { Standard } \\
\text { D }\end{array}$ & 9.5 & & 10.9 & & 11.3 & & 8.3 & & 9.9 & \\
\hline
\end{tabular}

Source: Computed from Field Survey, 2018

\section{Marital Status of Respondents}

Figure 3 shows the marital status of major actors in the cassava value chain in the study area.It was revealed in the figure that all the input suppliers (100\%) were married. For the producers, about $9.7 \%$ of the respondents were single, $69.3 \%$ were married, 12.75 were widowed and $8.3 \%$ were separated. Again, about $80 \%$ of the processors were married, while $9.0 \%$ and $11.1 \%$ of them were single and widowed respectively. Many $(65 \%)$ of the marketers were married, while $24.3 \%$ of them were single and $11.7 \%$ of the marketers were widowed in the area. Most married people have dependents and thus require a steady source of income. This is not the case with unmarried people. This result implied that most of the respondents were married, though some were single, widowed and few were divorced. This supports the findings of Adebayo et al. (2017) who noted most actors were married.

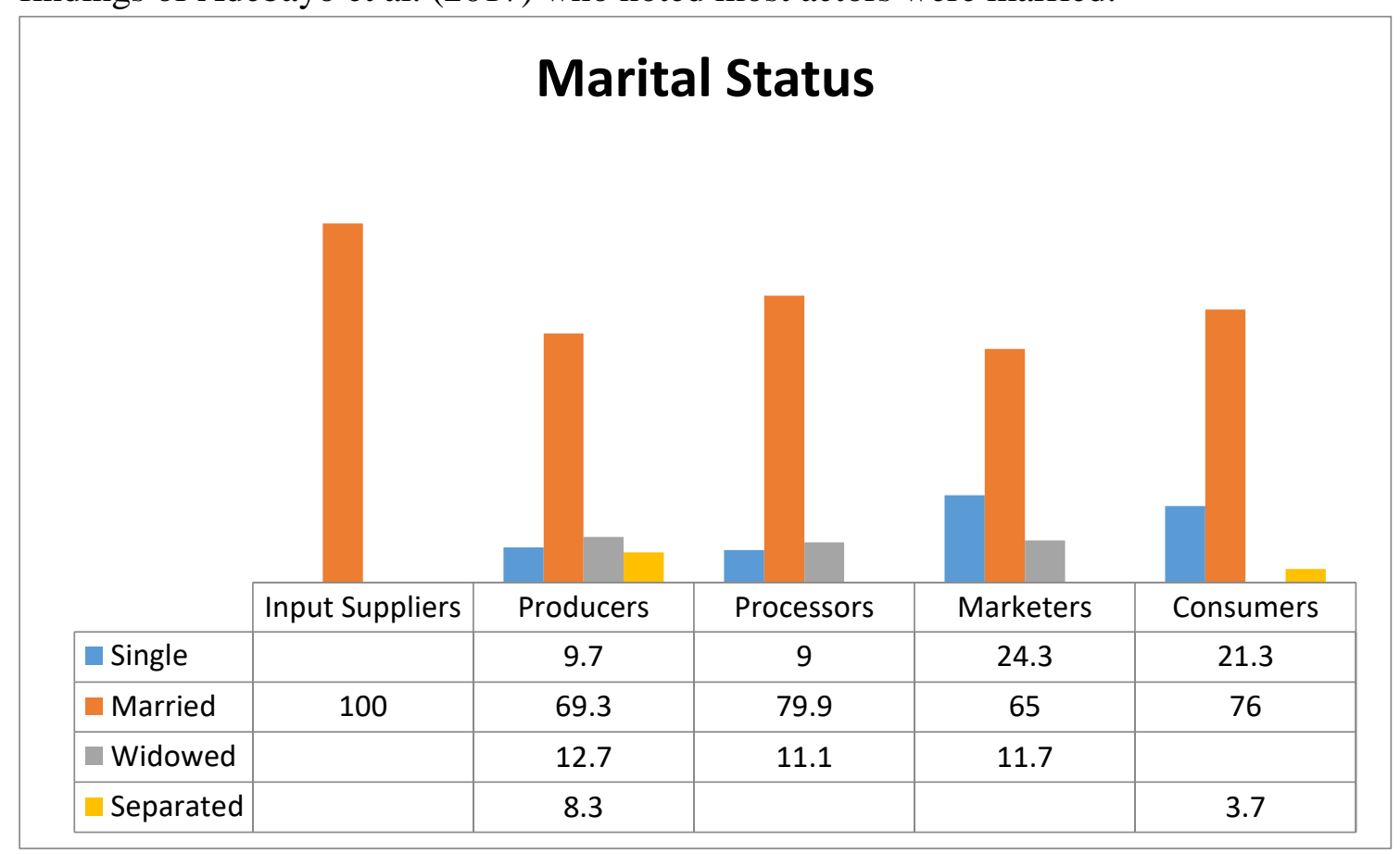

Figure 3: Marital Status Distribution of Respondents

Source: Computed from Field Survey, 2018 


\section{Household Size}

Table 3 shows the household distribution of the respondents. The results revealed that $73.3 \%$ of the input suppliers had between 1 and 5 household members, 26.7\% had between 6 and 10 household members. The mean household size for the input supplier was 4 persons per household. Some $(54.2 \%)$ of the producers had household size between 1 and 5 members, while $43.1 \%$ had between 6 and 10 household members. The mean household size for the producers was 5 persons. About $77.8 \%$ of the processors had between 1 and 5 household members, and $22.2 \%$ had between 6 and 10 household members. The mean household size for the processors was 5 . Likewise, about $80.0 \%$ of marketers had between 1 and 5 household members, while $20.0 \%$ of them had between 6 and 10 household members. The mean household size for the marketers was 5. Also, the result revealed that $46.7 \%$ of the consumers had between 1 and 5 household members and 53.3\% of them had between 6 and 10 household members with the mean of 6 persons in their households. The study affirms that all the actors in the value chain have moderate household size. This result could imply that moderate household sizes influence their investment on value addition activities as they might spent less on meeting the basic needs of the households. These findings are similar to the study of Balogun and Obi-Egbedi (2012), who found out in their study among cassava farmers in Southwest Nigeria that the average household size was six (6) people.

Table 3

Household Size Distribution of Respondents

\begin{tabular}{|c|c|c|c|c|c|c|c|c|c|c|}
\hline \multirow{2}{*}{$\begin{array}{c}\text { Househo } \\
\text { ld } \\
\text { Size }\end{array}$} & \multicolumn{2}{|c|}{ Input suppliers } & \multicolumn{2}{|c|}{ Producers } & \multicolumn{2}{|c|}{ Processors } & \multicolumn{2}{|c|}{ Marketers } & \multicolumn{2}{|c|}{ Consumers } \\
\hline & $\begin{array}{l}\text { Frequen } \\
\text { cy }\end{array}$ & $\begin{array}{l}\text { Perce } \\
\text { nt }\end{array}$ & $\begin{array}{l}\text { Frequen } \\
\text { cy }\end{array}$ & $\begin{array}{l}\text { Perce } \\
\text { nt }\end{array}$ & $\begin{array}{l}\text { Frequen } \\
\text { cy }\end{array}$ & $\begin{array}{l}\text { Perce } \\
\text { nt }\end{array}$ & $\begin{array}{l}\text { Frequen } \\
\text { cy }\end{array}$ & $\begin{array}{l}\text { Perce } \\
\text { nt }\end{array}$ & $\begin{array}{l}\text { Frequen } \\
\text { cy }\end{array}$ & $\begin{array}{l}\text { Perce } \\
\text { nt }\end{array}$ \\
\hline 1 to 5 & 11 & 73.3 & 39 & 54.2 & 56 & 77.8 & 60 & 80.0 & 34 & 46.7 \\
\hline 6 to 10 & 4 & 26.7 & 31 & 43.1 & 16 & 22.2 & 15 & 20.0 & 38 & 53.3 \\
\hline$>10$ & & & 2 & 2.7 & & & & & & \\
\hline Total & 15 & 100.0 & 72 & 100.0 & 72 & 100 & 75 & 100 & 72 & 100 \\
\hline $\begin{array}{l}\text { Minimu } \\
\mathrm{m}\end{array}$ & 1 & & 1 & & 1 & & 3 & & 2 & \\
\hline $\begin{array}{l}\text { Maximu } \\
\mathrm{m}\end{array}$ & 9 & & 8 & & 8 & & 7 & & 8 & \\
\hline Mean & 4 & & 5 & & 5 & & 5 & & 6 & \\
\hline $\begin{array}{l}\text { Standard } \\
\text { D. }\end{array}$ & 2.7 & & 2 & & 2.4 & & 1.2 & & 1.2 & \\
\hline
\end{tabular}

Source: Computed from Field Survey, 2018

\section{Level of Education}

The result in figure 4 revealed that $13.3 \%$ of the input suppliers had primary education, $26.7 \%$ had secondary education and $60.0 \%$ had tertiary education. Likewise, $20.8 \%$ of the producers had primary education, $48.6 \%$ had secondary education and $30.6 \%$ had tertiary education. Also, $22.2 \%$ of the processors had primary education, $11.1 \%$ had secondary education and $66.7 \%$ had tertiary education. This implies that all the sampled input suppliers, producers and processors were literate and this will help them in adopting innovative technologies. For the 
marketers, $18.7 \%$ had no formal education, $20.0 \%$ of the marketers had primary education, $50.7 \%$ had secondary education and $10.6 \%$ had tertiary education. Most $(80.0 \%)$ of the consumers had secondary education, $13.3 \%$ had primary education and $6.7 \%$ had tertiary education. The result showed that the actors in cassava value chain were educated with most of the processors and input supplier attaining tertiary education. The attainment of tertiary education could be the reason for positioning themselves at the two important stages of input supplies and processing in the value chain. This corroborates the study of Cucagna and Goldsmith (2017) which reported that the players in cassava value chain were well educated and informed.

\section{Level of Education}

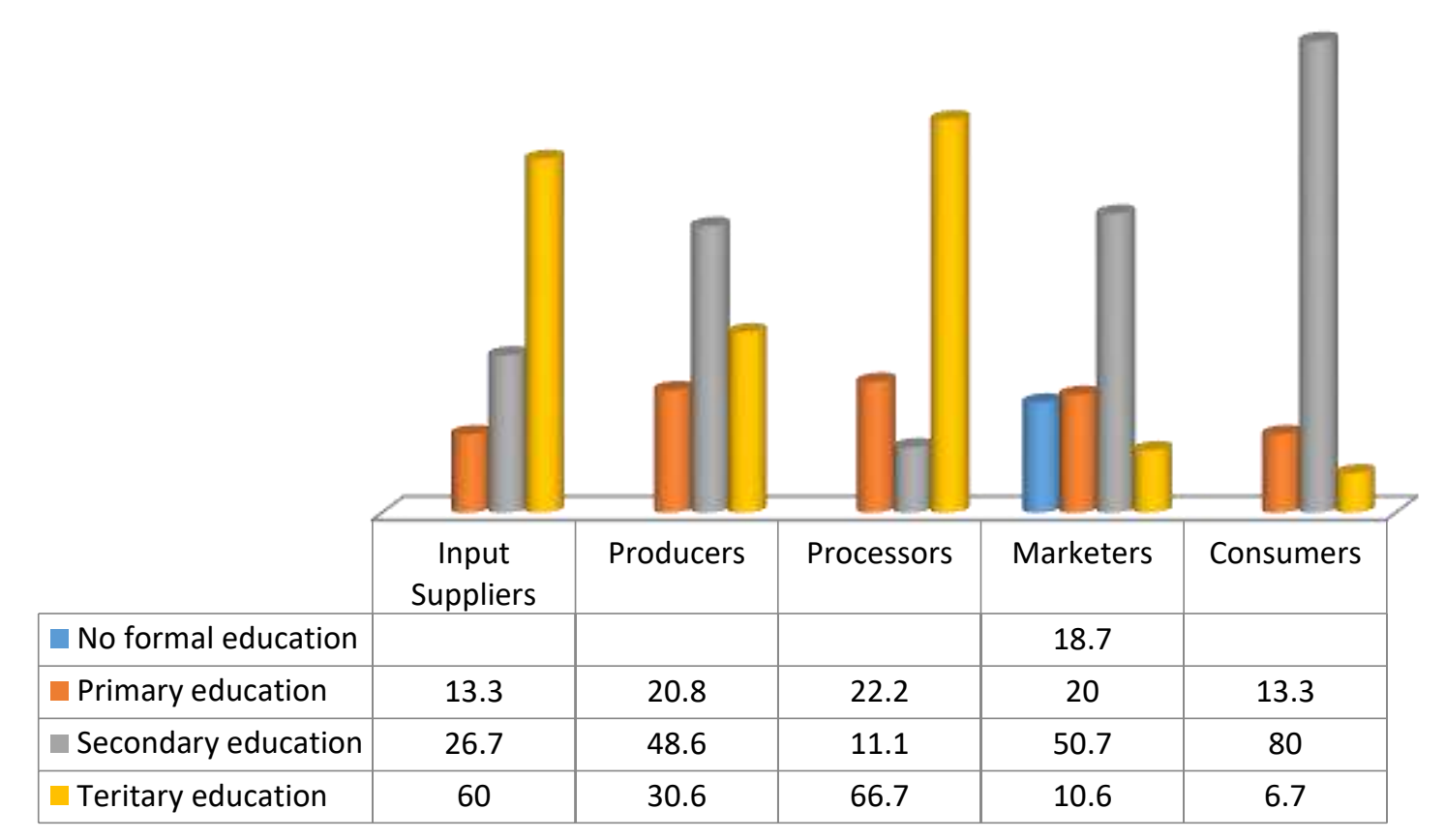

Figure 4: Distribution of respondents by level of education

Source: Computed from Field Survey, 2018

\section{Income}

The result in Table 4 revealed that $80.0 \%$ of the input suppliers earned less than or equal to N200, 000 per annum from input supplied, 13.3\% earned between N200, 001 and N400, 000 and $6.7 \%$ earned between N400, 001 and N600, 000. The mean income of input supplier was N196, 666. Most (70.8\%) of the producers earned less than or equal to N200,000 per annum while about $29.2 \%$ of them earned between N200,001 and N400,000. The mean income of producer was N151, 041. Likewise, $66.7 \%$ of the processors earned less than equal to N200,000, 11.1\% earned between 200,001 and 400,000, 11.1\% earned between 400,001 and 600,000 and $11.1 \%$ earned above 600,000. The mean income of processor was N224, 500 . Almost an average (49.3\%) of the marketers earned between N200, 001 and N400, 000, $30.7 \%$ earned less than N200, 001 and $20.0 \%$ earned above N600, 000. The mean income of marketers was N314, 786. The mean income of consumers was N47, 000. The marketers earn highest income among the actors followed by the processors, input suppliers and producers. Onyibe (2014) and Olomola (2017) noted that the earnings of the actors in the value chain vary. While, Olomola agreed that marketers earn most among the cassava value chain actors, Onyibe (2014) reported input suppliers have highest income. 
Table 4

Annual Income Distribution of Respondents

\begin{tabular}{|c|c|c|c|c|c|c|c|c|c|c|}
\hline \multirow{2}{*}{$\begin{array}{l}\text { Annual } \\
\text { Income } \\
(\#)\end{array}$} & \multicolumn{2}{|c|}{ Input suppliers } & \multicolumn{2}{|l|}{ Producers } & \multicolumn{2}{|c|}{ Processors } & \multicolumn{2}{|c|}{ Marketers } & \multicolumn{2}{|c|}{ Consumers } \\
\hline & $\begin{array}{l}\text { Frequen } \\
\text { cy }\end{array}$ & $\begin{array}{l}\text { Perce } \\
\text { nt }\end{array}$ & $\begin{array}{l}\text { Frequen } \\
\text { cy }\end{array}$ & $\begin{array}{l}\text { Perce } \\
\text { nt }\end{array}$ & $\begin{array}{l}\text { Frequen } \\
\text { cy }\end{array}$ & $\begin{array}{l}\text { Perce } \\
\text { nt }\end{array}$ & $\begin{array}{l}\text { Frequen } \\
\text { cy }\end{array}$ & $\begin{array}{l}\text { Perce } \\
\text { nt }\end{array}$ & $\begin{array}{l}\text { Frequen } \\
\text { cy }\end{array}$ & $\begin{array}{l}\text { Perce } \\
\text { nt }\end{array}$ \\
\hline $\begin{array}{l}0 \\
200000\end{array}$ & 12 & 80.0 & 51 & 70.8 & 48 & 66.7 & 23 & 30.7 & 72 & 100.0 \\
\hline $\begin{array}{l}200001- \\
400000 \\
400001\end{array}$ & 2 & 13.3 & 21 & 29.2 & 8 & 11.1 & 37 & 49.3 & & \\
\hline $\begin{array}{l}- \\
600000\end{array}$ & 1 & 6.7 & & & 8 & 11.1 & 15 & 20.0 & & \\
\hline $\begin{array}{l}\text { above } \\
600000\end{array}$ & & & & & 8 & 11.1 & & & & \\
\hline $\begin{array}{l}\text { Minimu } \\
\mathrm{m}\end{array}$ & 20000 & & 35000 & & 52500 & & 160000 & & 20000 & \\
\hline $\begin{array}{l}\text { Maximu } \\
\text { m }\end{array}$ & 730000 & & 370000 & & 73000 & & 825000 & & 90000 & \\
\hline Mean & 196666 & & 151041 & & 224500 & & 314786 & & 47000 & \\
\hline $\begin{array}{l}\text { Standard } \\
\text { Deviatio } \\
\mathrm{n}\end{array}$ & 23800 & & 19139 & & 20741 & & 20958 & & 15200 & \\
\hline
\end{tabular}

Source: Computed from Field Survey, 2018

\section{Membership of Cooperative Societies}

The distribution of respondents according to their membership of cooperative societies was presented in Figure 5. The result revealed 80.0\%, 66.7\%, 42.7\% and $100.0 \%$ of the input suppliers, producers, processors and marketers respectively belong to one cooperative society or the other. Also, $40 \%$ of the consumers belonged to one cooperative or the other. The implication here is that most of the actors in the cassava value chain belong to one cooperative society or the other which could be a major support to their business in cash or kind. Belonging to one for of cooperative societies is very important as it provide credits to the participant in form of cash or inputs. According to Amos (2013), membership of association is of immense benefits to members, it gives opportunity for bulk purchase of inputs at discounted rates and helps members secure credit facilities as at when due.

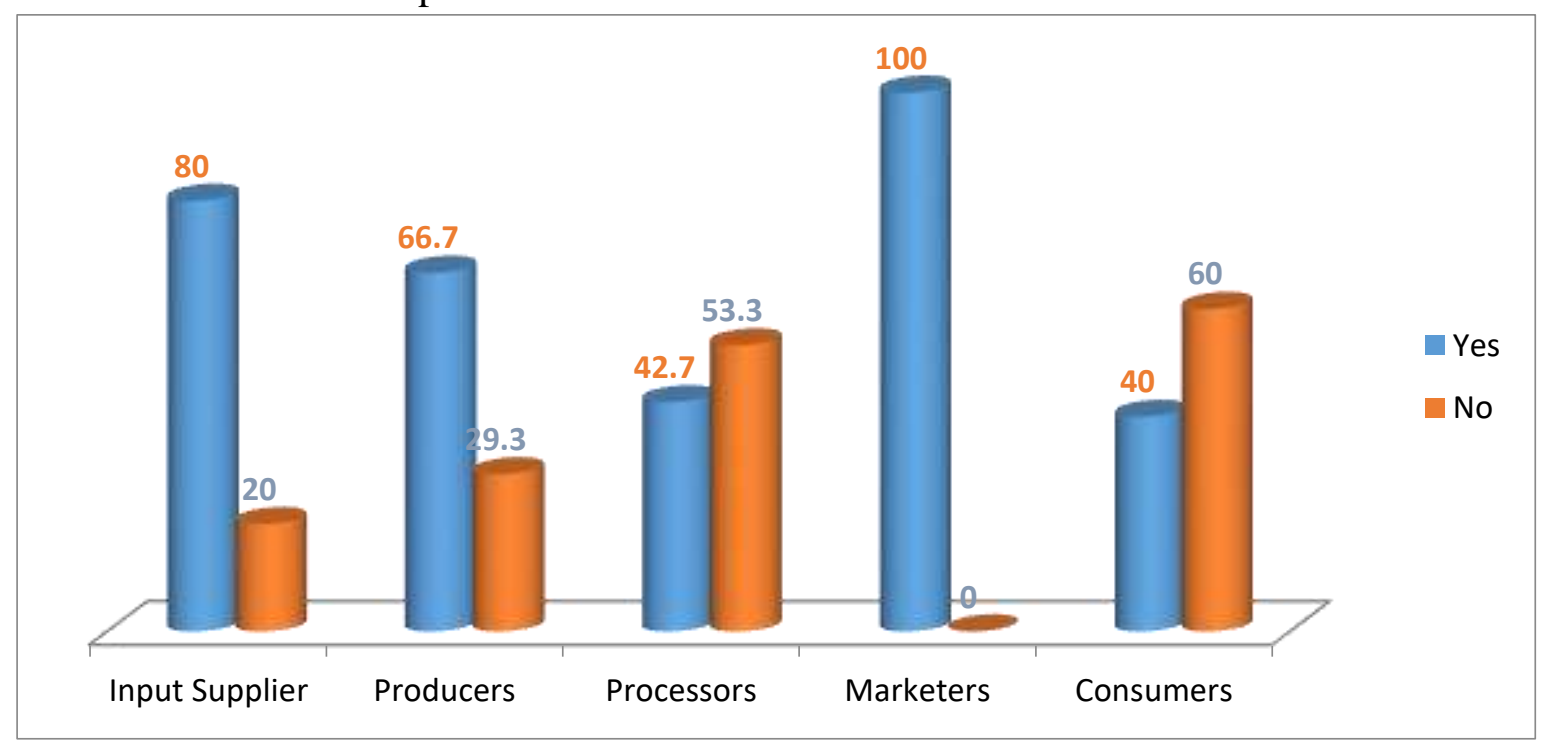

Figure 5: Distribution of Respondents according to their Membership of Cooperative Society 


\section{Years of Membership of Cooperative Society}

Table 5 shows the distribution of respondents based on their years of cooperative society membership. According to the results, 66.7 percent of the input suppliers joined the cooperative society between 1 and 5 years, 20.0 percent between 6 and 10 years, and 13.3 percent between 11 and 15 years. Most (61.1\%) of the producers had between 1 to 5 years and $25.0 \%$ had between 6 to 10 years and $13.9 \%$ had above 10 years. Likewise, $88.9 \%$ of the processors had between 1 to 5 years and $11.1 \%$ had between 6 to 10 years of membership in cooperative society. Furthermore, $73.3 \%$ of the marketers had been member of cooperative society for less than 6 years and $26.7 \%$ had between 6 to 10 years of membership in cooperative society. Likewise, $73.4 \%$ of the consumers had between 1 to 5 years, $13.3 \%$ had between 6 to $10 \%, 13.3 \%$ had above 10 years of membership in cooperative society. The mean years spent as a member of cooperative societies were 4.4, 3.9, 2.1, 4.4 and 3.9 for input suppliers, producers, processors, marketers and consumers respectively. The result showed that most of the actors in the cassava value were new to cooperative membership.

Table 5

Distribution of Respondents by Years of Cooperative Society Membership

\begin{tabular}{|c|c|c|c|c|c|c|c|c|c|c|}
\hline \multirow{2}{*}{$\begin{array}{c}\text { Years of } \\
\text { membersh } \\
\text { ip }\end{array}$} & \multicolumn{2}{|c|}{ Input suppliers } & \multicolumn{2}{|c|}{ Producers } & \multicolumn{2}{|c|}{ Processors } & \multicolumn{2}{|c|}{ Marketers } & \multicolumn{2}{|c|}{ Consumers } \\
\hline & $\begin{array}{l}\text { Frequen } \\
\text { cy }\end{array}$ & $\begin{array}{l}\text { Perce } \\
\text { nt }\end{array}$ & $\begin{array}{l}\text { Frequen } \\
\text { cy }\end{array}$ & $\begin{array}{l}\text { Perce } \\
\text { nt }\end{array}$ & $\begin{array}{l}\text { Frequen } \\
\text { cy }\end{array}$ & $\begin{array}{l}\text { Perce } \\
\mathrm{nt}\end{array}$ & $\begin{array}{l}\text { Frequen } \\
\text { cy }\end{array}$ & $\begin{array}{l}\text { Perce } \\
\text { nt }\end{array}$ & $\begin{array}{l}\text { Frequen } \\
\text { cy }\end{array}$ & $\begin{array}{l}\text { Perce } \\
\text { nt }\end{array}$ \\
\hline 1 to 5 & 10 & 66.7 & 44 & 61.1 & 64 & 88.9 & 55 & 73.3 & 52 & 73.4 \\
\hline 6 to 10 & 3 & 20.0 & 18 & 25.0 & 8 & 11.1 & 20 & 26.7 & 10 & 13.3 \\
\hline$>10$ & 2 & 13.3 & 10 & 13.9 & & & & & 10 & 13.3 \\
\hline Total & 15 & 100.0 & 72 & 100.0 & 72 & 100 & 75 & 100 & 72 & 100 \\
\hline Minimum & 0 & & 0 & & 0 & & 1 & & 0 & \\
\hline Maximum & 15 & & 10 & & 8 & & 10 & & 20 & \\
\hline Mean & 4.4 & & 3.9 & & 2.1 & & 4.4 & & 3.9 & \\
\hline $\begin{array}{l}\text { Standard } \\
\text { D }\end{array}$ & 0.4 & & 0.8 & & 0.2 & & 1.3 & & 1.6 & \\
\hline
\end{tabular}

Source: Computed from Field Survey, 2018

\section{Extension}

Figure 6 showed that $33.3 \%$ of the input suppliers had access to extension services and $66.7 \%$ did not have access to extension services. Also, $61.1 \%$ of the producers had access to extension services and $38.9 \%$ did not have access to extension services. It further revealed that $42.7 \%$ of the processors had access to extension services and $53.3 \%$ did not have access to credit facilities. Above average $(52 \%)$ of the marketers had access to extension services and $48.0 \%$ had no access to extension services. This implies that most of the input suppliers in area were not privileged to benefit from extension education and training but it is on the contrary for the producers as most of them had access to extension service which could impact them positively in terms of information and innovative technologies to take good decisions that will increase their production level. Umar (2009) argued that higher extension contacts would increase adoption of improved farm production technologies. They further argued that the frequency of extension contact is very essential as it guides the farmers from awareness stage to the adoption stage. 


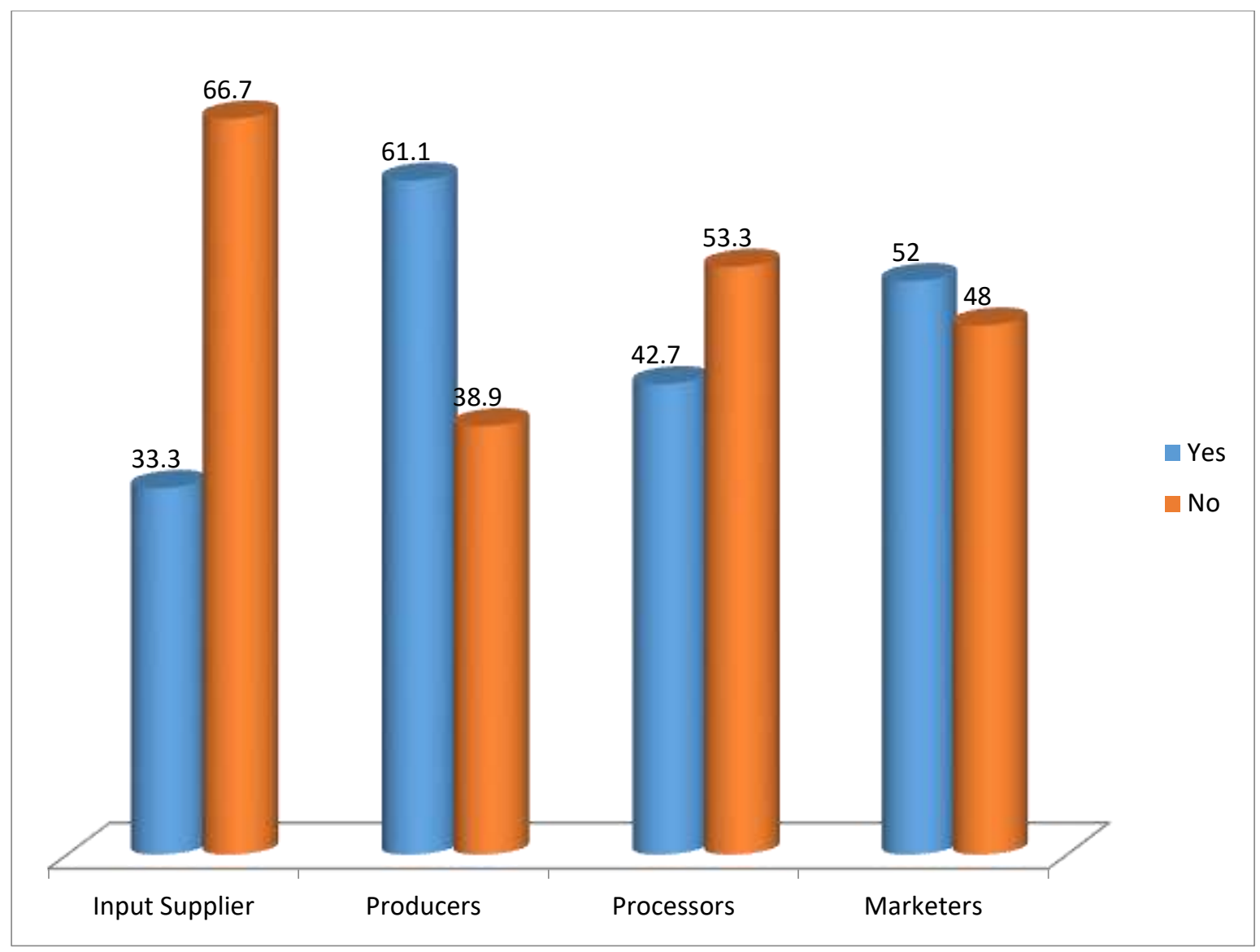

Figure 6: Distribution of Respondents according to their Access to Extension Services Source: Field Survey, 2018

\section{Access to Credit}

Figure 7 revealed that $86.7 \%$ of the input suppliers did not have access to credit facilities. Also, $58.3 \%$ of the producers did not have access to credit facilities. It further revealed that $77.8 \%$ of the processors did not have access to credit facilities and all (100\%) of the marketers had no access to credit facilities in the area. The study showed that the entire participant in the value chain did not have access to credit which could hinder their efficiency in the cassava value chain.

According to Fasoranti (2006), poor accessibility to credit facilities coupled with nonmembership of cooperative societies may count for the poor financial base of farmers and hence inability to employ modern farm implements and resultant poor productivity.

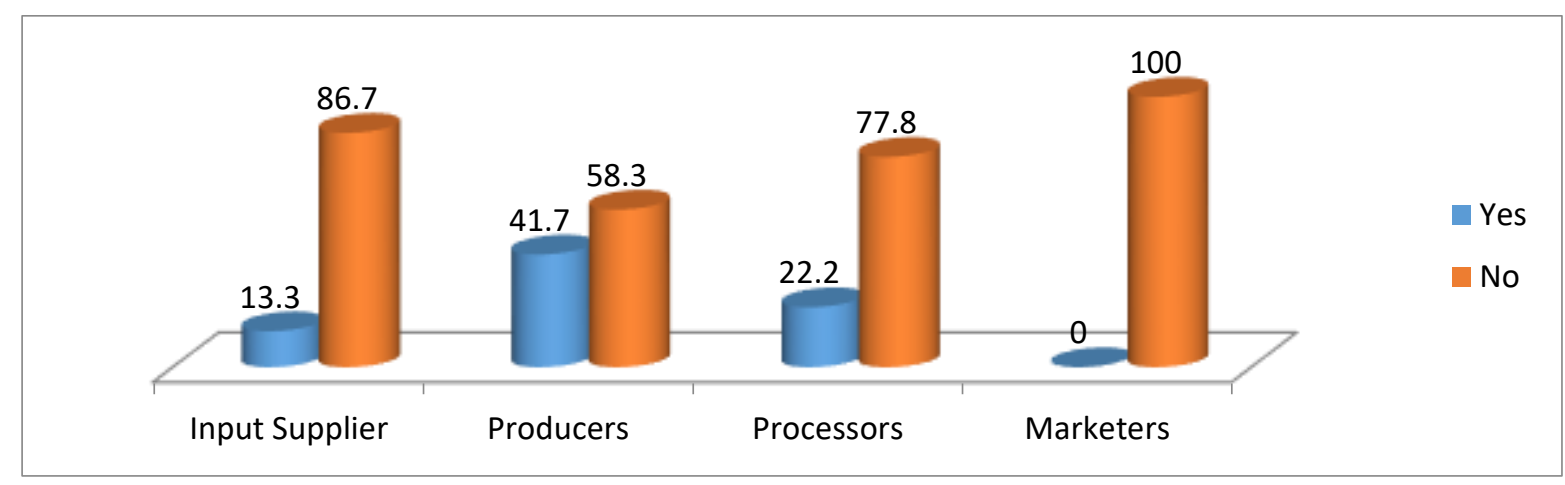

Figure 7 Distribution of Respondents according to their Access to Credit Facilities Source: Computed from Field Survey, 2018 


\section{Sources of Capital}

The distribution of the respondents by their sources of capital was presented in Figure 8. It revealed that $33.3 \%$ of the input supplier source their capital from personal savings, $60.0 \%$ had cooperative societies as their source of capital and $6.7 \%$ sourced for capital from banks. Majority $(30.6 \%)$ of the producers sourced capital from personal savings with the least (11.1\%) from friends and relatives. In addition, most $(44.4 \%)$ of the processors sourced for capital from their personal savings and 39.2\% sourced from cooperative societies. Likewise, $80.0 \%$ of the marketers sourced for capital from personal savings, $10.7 \%$ sourced from cooperative society and $9.3 \%$ sourced from banks. The result revealed that the two main sources of capital were personal savings and cooperative societies. It showed how instrumental the cooperative societies were to the success of the cassava value chain actors. The low percentages recorded in banks could be due to stiff bank policies on loan disbursement. Friends and relatives as well as gifts took the lowest share; this could be because people could not commit their money into the hands on other people. The study by World Business Council for Sustainable Development (WBCSD) (2018) identified the major sources of capital for entrepreneurs in Agriculture as personal savings and cooperative societies. The report noted that commercial banks introduced rigid procedures for loan procurement; this makes it difficult for entrepreneurs to access capital from banks.

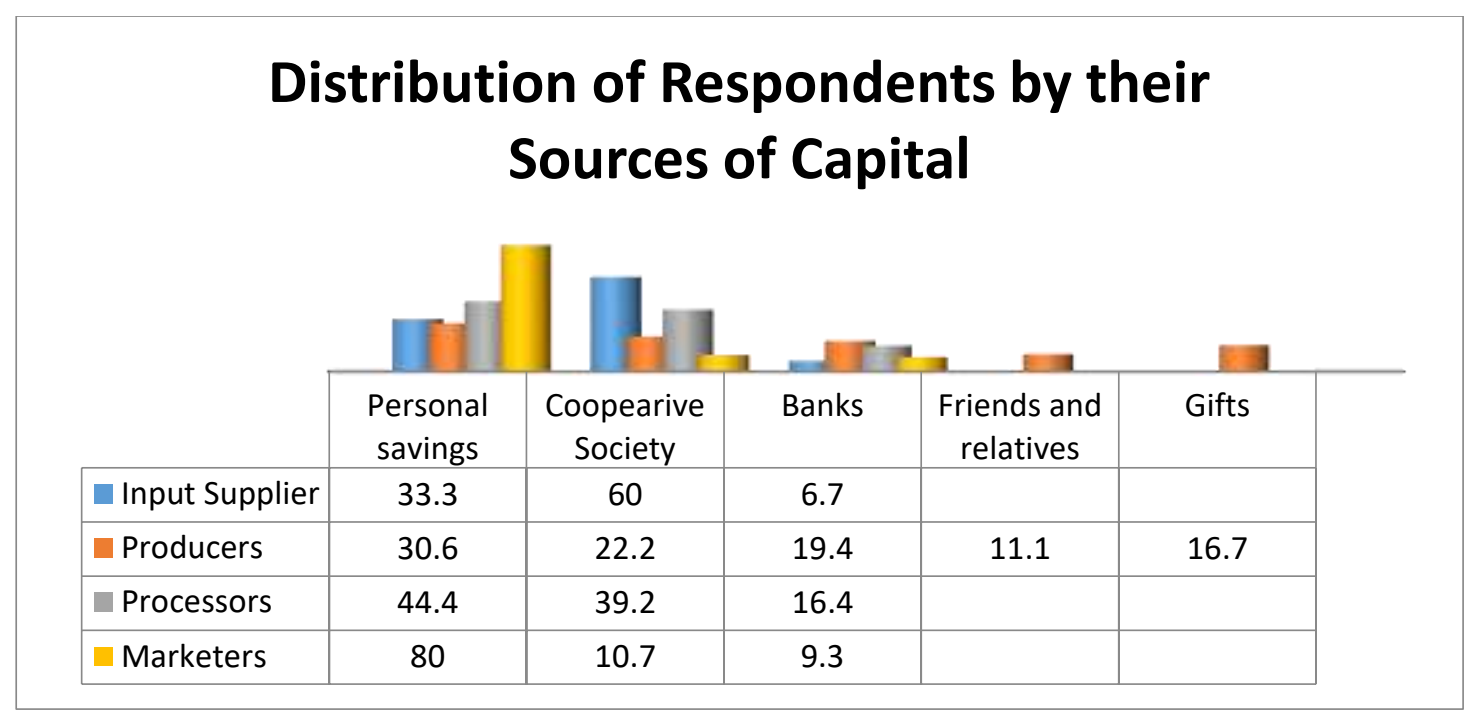

Figure 8: Distribution of Respondents by their Sources of Capital Source: Computed from Field Survey, 2018

\section{Cassava Value Chain Showing Dependencies and Linkages}

The Nigerian Cassava Value Chain was presented in Figure 9, and it showed the dependencies that existed between the actors of the chain and how the products flow from the input suppliers to the ultimate consumers.

The chain started from the inputs suppliers which could be public or private. Also, the research institutes such as International Institute for Tropical Agriculture (IITA) and other governmental and non-governmental agencies serves as agro-dealers and input providers. The results of FGDs and Mapping findings revealed input suppliers usually supply agrochemicals and tractors.

'... They normally supply crude implements such as hoes and cutlasses, fertilizers, herbicides, stem cuttings and knapsack sprayer. For cooperative farmers, Fadama groups and individuals that operate on a large scale normally receive machineries such as tractors mounted ploughers, harrowers from the input suppliers. Though suppliers of machineries in 
Ekiti State were few, and the major suppliers were: AVIL Machineries, and the government through Ministry of Agriculture and Agricultural Development Programmes (ADP) has helped to facilitate the supplies of improved inputs and machineries but ... (Participants at Erinfun in Ado LGA).

The producers were the cassava farmers who cultivated small, medium and large scale of cassava production. The report of FDGs in one of the communities visited was presented below.

'...we mostly produce for family consumption and as well produce for market purpose. The size of our farm for cassava is what we are using to determine the scale of production in this area. Some of us plant cassava alone, while many of us plant cassava with other crops such as pepper, yam, okro, and other vegetables...' (Participants at Ilasa, Omuo in Ekiti East LGA).

They incur various costs (fixed and variables) ranging from which range from land, labour, chemicals and entrepreneur cost. All these constitute the inputs used for production on the farm. Farmers in one of the communities buttressed the costs incurred in the production of cassava in the area and the FGDs report is stated thus:

'...the variable inputs we used are the cassava stems which were gotten from the previous harvest, friends/relatives, ADP, research institutes and private/shopkeeper suppliers. We cultivate the cassava from planting to harvesting while the tubers are either sold while in the heaps or they harvest and sold the tubers at the farm gate to travelling traders who sold the tubers in another town/city, or to the rural assemblers and/or local markets. The price we sell at farm gate is relatively cheaper compare with the price middle men sell the tubers at the open market. This really gives us a concern as we call ...' Excerpt from FDGs at Ifaki in Ido-Osi LGA.

The processors were the actors who covert the raw tubers to consumable products, such as garri, lafun, fufu, High Quality Cassava Flour (HQCF)for other production. Most of the value additions to cassava products were done by the processors. This is buttressed with the report of FGDs held with the processors and their statements were transcribed thus:

'...we normally buy from the producers (farmers) either in wholesale or small quantities depending on their scale of business. The different products have different channels of production, value additions and supply channels. In this area, we were equipped as processors with various processing techniques and machineries, ranging from the crude to the advanced methods. We in the cooperative society and Fadama groups were advantageous over other cassava processors in the town. Through the help of Government and World Bank, we were exposed to training and given some equipment that we used in our community for processing cassava to different products. Some of the equipment is grinder, presser, fryer and stores...' Excerpt from FDGs at Erinfun in Ado LGA.

The fourth actors were the marketers/middlemen. They were saddled with the responsibility of making the cassava products available for markets and consumers. The report from the FGDs revealed that they got the highest share in the profit margin of cassava value chain and stated as:

'...we performed value addition in response to the consumers' preferences. We buy cassava tuber from the farmers. We always buy from their farm in order to make more profit and it is cheaper in the farm than the open market. That is how we make more profit than any other actors in the chain. We do sell cassava products as wholesales, retails and export, depending on the scope of business and market. Again, many consumers do come to our store 
or mill to buy the products most especially gaari. How we process the products and the value we add will determine the price sometimes that is while there is always variations in the price across the communities...' (Participants at Ipoti in Ijero LGA).

The ultimate consumers were the last on the cassava value chain. They determine the scope of production, the types of products, value addition to be done in accordance to their preference. It was ascertained from the FGDs and Mapping that the consumers of cassava products were diverse and consume varieties of cassava products and they stated thus:

'...we bought in large and small quantities depending on the commodity's price and the money at hand. Since is the cassava products are the common food that are accessible and affordable, we also buy based on the needs and as well buy often whether in the local market, shops, stores or processing centres. Processing centres and stores are relatively cheaper compare with local markets and local market is cheaper compared with shops. Other factors that determine purchase of cassava and cassava products are household size, income, taste, colour, and preference. In summary, we can also say that we buy cassava products from travelling traders, local markets, processors, wholesalers and retailers...' Excerpt from FDGs in Ado LGA.

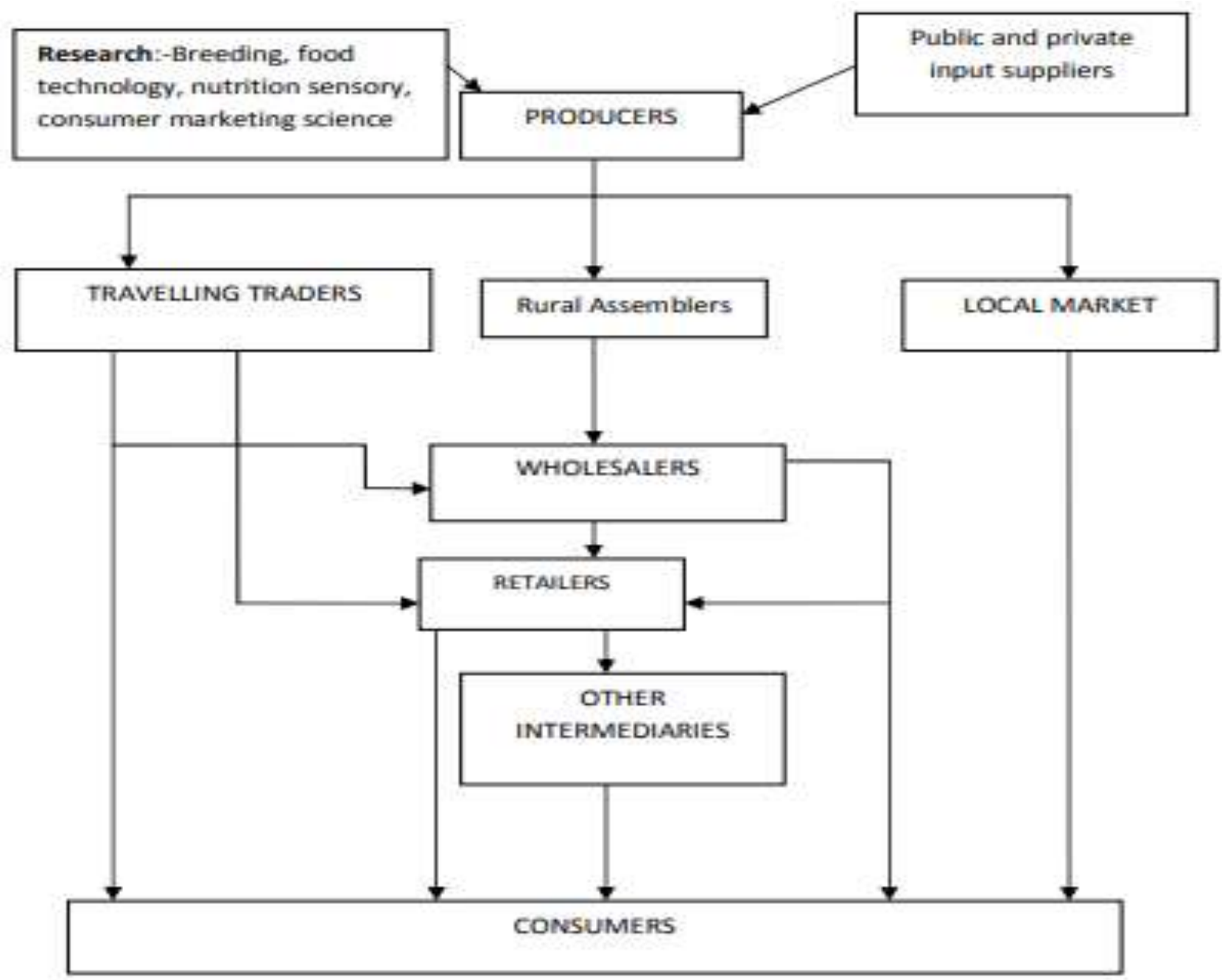

Figure 9: Cassava Value Chain Showing Dependencies and Linkages Source: Drawn from survey data /focus group meeting 


\section{Actors of the Cassava Value Chain \\ Garri, Fufu, Pupuru and Lafun}

In order to find new industrial market development opportunities in the country that could drive the sub-sector, the above described supply chain presents the following status:

Garri, fufu, pupuru and lafun were commonly consumed cassava products in the study area, thus they follow the same structure in the cassava value chain map. Figure 4.9 describes the structure of these cassava products from the input supplier to the producers who were the farmers to the processors who convert the cassava tubers into various forms and sold at gate and local markets or they sold to middlemen who later sold for retail or urban consumption. Input suppliers: they are the first actor in the cassava value chain; they supplied value in the form of inputs needed for profitable cassava production. The FGDs report stated thus:

'...we supply inputs such as cassava stems, pesticides, herbicides, fertilizers (organic and inorganic), crude implements such as cutlasses, hoes and machineries such as tractors, ploughers for land preparation. The input suppliers registered agro-dealers, research institutes and retail suppliers and supplied the inputs to the producers of cassava...' Excerpt From FDGs at Ifaki in Ido-Osi LGA.

Producers: these were the farmers who were involved in the cultivation of cassava and got their input from the input suppliers or from previous harvest. They perform activities such as land preparation, planting, fertilizer application, usage of chemicals (pesticides, herbicides), weeding and sometimes harvesting. From the FGDs and Mapping reports, it was pinpointed that:

'...we sold our cassava tubers while still in the soil, thus the middlemen or processor did the harvesting of the cassava...' (Participants from Ado in Ado LGA).

Processors: they buy cassava tubers (raw products) from the producers (farmers) and changed the form (utility of form). They convert the cassava tubers to the desired products such as garri, fufu, pupuru and cassava flour (lafun). The FGDs findings opined thus:

'...though we have different processing stages but similar value addition. After the conversion, we sold the cassava products to middlemen or at the processing gates to local consumers or local market women who then sold them within the villages...' Excerpt from FDGs at Ayedun in Ikole LGA.

Micro-bulker or Middlemen: they bought the cassava products in bulk quantity from a single processor or a combination of processors. They bought at much lesser prices and sold the products in retail or wholesale quantities. Report from one of the FDGs further confirmed the statement below.

'...we normally buy in large quantity from the processors and after that we either sell in the market if the price is favour or store the products till the period of product-shortage. Value is added in the form of repackaging, sorting and flavor; this will also lead to incurring more cost of marketing which will invariably lead to more cost of purchase...' Excerpt from FDGs at Ado LGA.

Consumers: these were the final actors in the cassava value chain. They demand for these products with respect to their preference, taste, price of the products, price of substitute products, income amongst other factors as earlier reported in the previous section. 


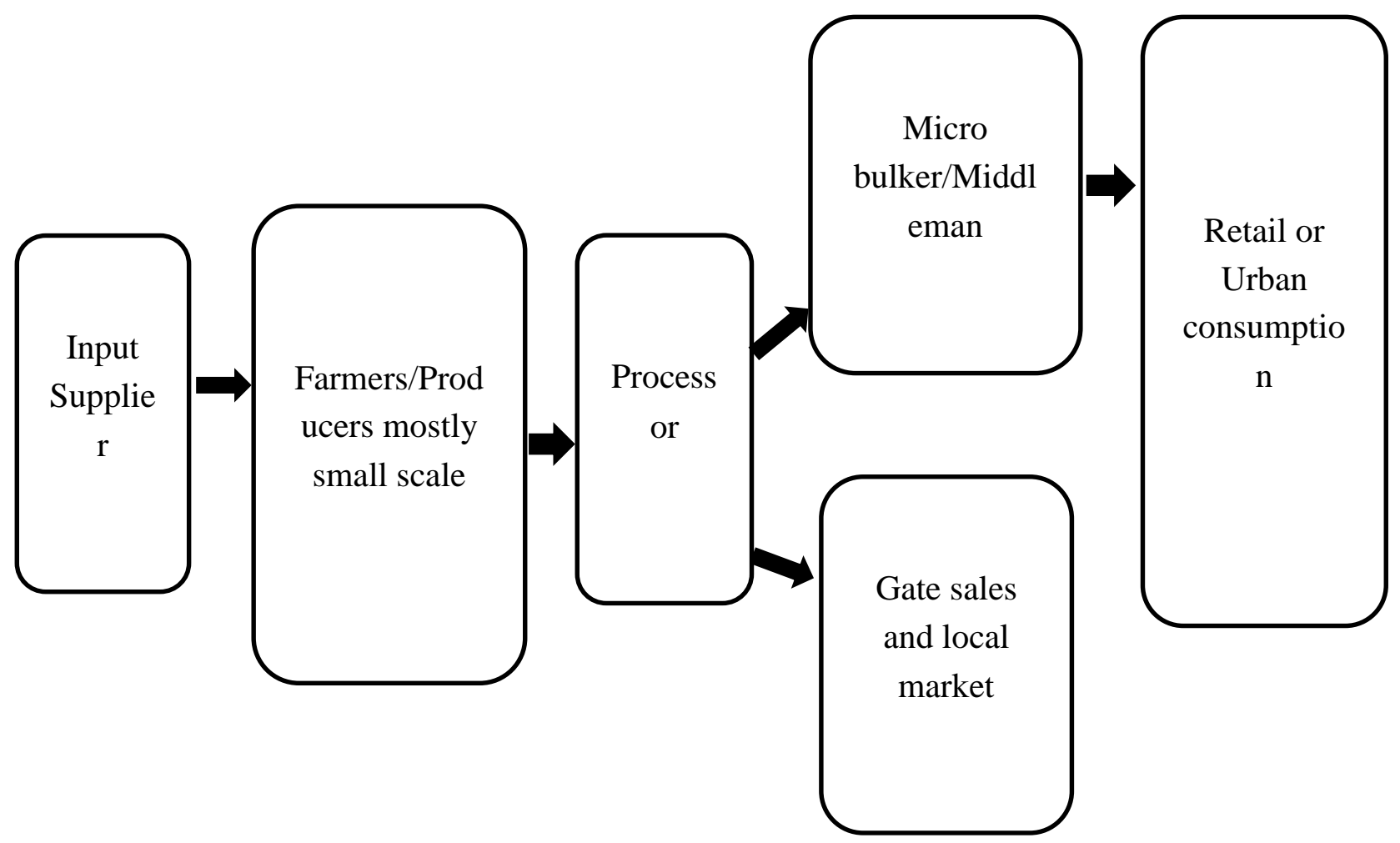

Figure 10: Cassava Value Chain Map for Garri, Fufu, Pupuru and Lafun

Source: Drawn from survey data /focus group meeting

\section{Chips Value Chain}

In the chips value chain, the input suppliers were the first actor in the chip value chain. They supply inputs to the producers of cassava which were mostly on medium and large scale. The report from FGDs was transcribed thus:

'...the producer market groups get the fresh cassava tubers and send them to the processing centre. After conversion to chips, they were sold to the wholesalers and finally to the retailer for immediate consumption or export... ' Excerpt from FDGs at Ado LGA.

Input suppliers: they provide the needed materials for successful cassava production. Inputs such as machineries, improved cassava stems, chemicals (pesticides, herbicides), fertilizers (organic and inorganic) and others.

Scale producers: these are the producers (farmers) who cultivate cassava on a medium and/or large scale basically for chips production.

Producers' market groups: the next stage in the chip value chain was the producers' market groups collection centres. They collect fresh cassava from the scale farmers in large quantities and sold to the chips processing centres.

Chips processing centres: they bought cassava from the collection centres and convert the tubers to chips though various stages such as grating, peeling, and so on. The FGDs results found the mode of quanity sold as:

'...we produced in large quantities and sold to the wholesalers using different packages... ' Excerpt from FDGs at Ado LGA. 
Wholesalers: they bought chips in wholesale quantities from the processing centres, they repackaged, sorted them and sold to the retailers or exported to other countries such as Ghana. Retailers: they bought chips from the wholesalers in smaller quantities and transport them to the urban market for consumers to buy or export the chips to neighboring countries.

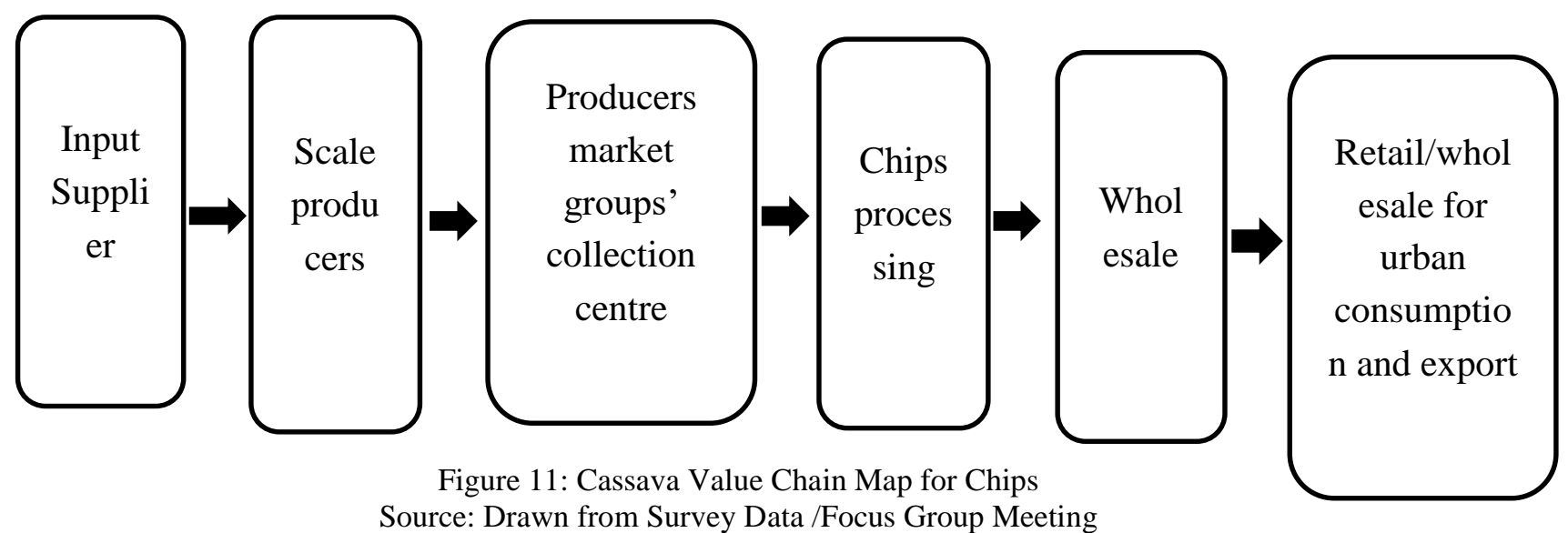

\section{High Quality Cassava Flour Value Chain}

The value chain for cassava flour was presented in Figure 12. The chain started from the input suppliers to the producers and later to the producers/market groups collection centres. After, it was divided to processors and millers; and from the processors to the supermarkets or urban/export markets which was also the end of millers.

Input suppliers: They supply inputs for the scale production, such as machineries, improved stem cuttings, fertilizers, pesticides and herbicides. Majorly, these input suppliers provided materials needed for production in bulk quantities.

Scale producers: They are the farmers that cultivate cassava in medium and large production. They have farm size of above 5 hectares; they were mainly in clusters in the study area.

Producers/market groups' collection centers: After production the cassava tubers were collated at the various collection centers, and then transferred to the processors and millers.

Milles: They were mainly large processors who were in charge of cassava flour production. They converted cassava tubers into cassava flour, thus sent them for exports and urban markets after packaging and other value addition.

Processors: They collected cassava tubers from the collection centers and processed them into flour. They were in stages, small, medium and large quantities and sold to the supermarkets.

Supermarkets: The supermarkets were mainly the outlet for cassava flour produced through the processors. The consumers bought cassava flour from the supermarkets.

Exports and/or urban markets: These were mainly the outlet of cassava flour after the millers has added value. The cassava flour was sold in large quantities for foreign exchange earnings. 

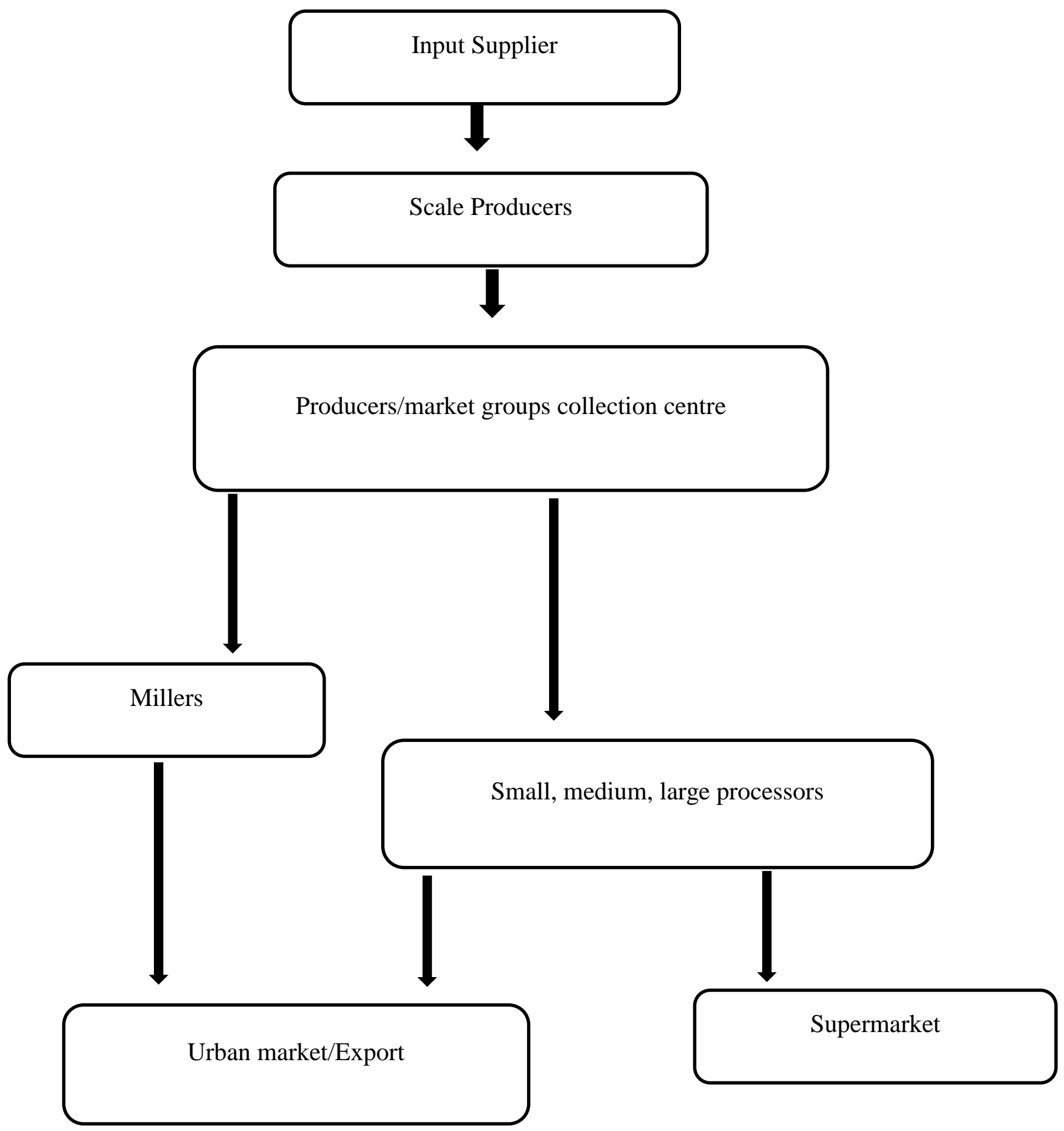

Figure 12: Cassava Value Chain Map for High Quality Cassava Flour Source: Drawn from Survey Data /Focus Group Meeting

\section{CONCLUSION}

The study concluded that actors in the cassava value chain in Ekiti State have diverse socioeconomic characteristics which may also be specific to the independent level of participation in the chain. These characteristics have some influence on the demand and supply of cassava and its products. Also, prices of agricultural produces determine the income level of actors (market participants) in agricultural value chain and thus affect their socioeconomic characteristics. The study recommends that government and non-governmental organization should enact policies and programmes aimed at equipping the actors of cassava 
value chain with needed skills and expertise as this will expose them the current trends and technologies for effective value chain and which may make them more suitable to access credit facilities from banks and other financial institutions. Financial institutions including banks and formal credit agencies should be controlled by the government through CBN to make less stiff laws and processes, so as to afford the players in cassava value chain the accessibility to loans and other credit facilities.

\section{References}

Adebayo, K., Abayomi, I., Abass, A., Dziedzoave, N. T., Forsythe, I., Hillocks, R. J., Gensi, R., Gibson, R. W. Graffham, A. J., Ilona, P. Kleih, U. K., Lamboll, R. I., Mahende, G., Martin, A. M. Onumah, G. E., Orr, A. W., Posthumus, H., Sanni, I. O., Sandifolo, V. \& Westby, A. (2017). Sustainable inclusion of smallholders in the emerging high quality cassava flour value chains in Africa: Challenges for Agricultural Extension Services. Journal of Agricultural Extension, 14(1), 1-10.

Adewole, S., \& Omeye, A. (2018). Effects of Financing on Cassava Value Chain in Owo Local Government Area, Ondo State, Nigeria. Scientific Papers Series Management, Economic Engineering in Agriculture and Rural Development, 18(1).

Cucagnaa, M. E., \& Goldsmith, P.D. (2017). Value adding in the agri-food value chain. International Food and Agribusiness Management Review, 19(4). DOI: 10.22434/IFAMR2017.0051

Henri-Ukoha, A., Anaeto, F.C., Chikezie, C., Ibeagwa, O. B., Ukoha, I.I., Oshaji, I.O., \& Anyiam, K.H., (2015). Analysis of Cassava Value Chain in Ideato South Local Government Area, Imo State, South-East Nigeria. International Journal of Life Sciences, 4(4), 209-215.

Mondal, E.O., Ndegwa, A.M., Munene, S. (2003). French beans production in Nkuene and Abogeta divisions of Meru Central District in Kenya. In proceedings of 6th Biennial African Crop Science Conference, 12th -17th Oct., 2003, Nairobi, Kenya.

Ogunwande, I. O., Akinrinola,O.O., \& Olasoji, O. A. (2020). Value Chain Analysis of Maize Production among Rural Households in Oyo State, Nigeria. IOSR Journal of Agriculture and Veterinary Science (IOSR-JAVS), 13(9), Ser. III.

Olomola, A. S. (2007). Competitive Commercial Agriculture In Africa Study (Ccaa) Nigeria Case Study. Final Report Submitted to the Canadian International Development Agency (Cida) and the World Bank

United State Agency for International Development (2009). A Study of The Cowpea Value Chain in Kano State, Nigeria, from A Pro-Poor and Gender Perspective, Greater access to trade expansion (GATE) project under the women in development, United State Agency for International development.

WBCSD (2018). Collaboration, innovation, transformation: Ideas and inspiration to accelerate sustainable growth - A value chain approach 